\title{
Ocular involvement in mucormycosis during COVID-19 and post-COVID 19 syndrome: a new challenge in ophthalmology
}

\author{
Fernando Godin-Estrada', Laura Alejandra Acevedo-Espitia ${ }^{2}$, Valentina Delgado ${ }^{2}$, \\ Michael Gregorio Ortega-Sierra ${ }^{3}$, Ivan David Lozada-Martinez ${ }^{4}$ \\ ${ }^{1}$ School of Medicine, Universidad el Bosque, Bogota, Colombia \\ ${ }^{2}$ School of Medicine, Universidad de La Sabana, Chía, Colombia \\ ${ }^{3}$ Medical and Surgical Research Center, Corporación Universitaria Rafael Nuñez, Cartagena, Colombia \\ ${ }^{4}$ Grupo Prometheus y Biomedicina Aplicada a las Ciencias Clinicas, School of Medicine, Universidad de Cartagena, Cartagena, Colombia
}

KEY WORDS: orbital diseases; COVID-19; orbital mucormycosis; post-COVID 19 syndrome

Ophthalmol J 2021; Vol. 6, 223-226

\section{TO THE EDITORS,}

The COVID-19 pandemic has substantially impacted all fields of medicine globally. Both surgical and non-surgical specialties have modified the approach to diseases, considering the difficulties in accessing tools, contact with patients, financing, infrastructure, and time availability $[1,2]$. This is a double-edged sword since it causes delays in managing acute, subacute, or chronic conditions, underdiagnosis or overdiagnosis, and inadequate therapeutic plans that may have repercussions in the genesis or decompensation of other diseases [1-4]. Mucormycosis is an emerging fungal infection that has raised global health alarms due to its association with COVID-19 [1-8]. Although this condition frequently affects the lungs, a major outbreak has been described in India and elsewhere in the world, with rhino-orbito-cerebral involvement, with morbidity, mortality and disability rates of concern (Tab. 1) [1-8].

Studies have shown that mucormycosis can occur both in the acute phase of COVID-19 and post-COVID-19 syndrome $[9,10]$. The latter is defined as the appearance or persistence of symptoms or conditions associated with the target organ lesion during the acute phase of COVID-19, which on average is 15-20 days after the onset of symptoms [9, 10]. Although little is known about the post-COVID 19 syndrome, there is no denying that it is a window of risk for fatal complications, especially in groups of patients with a history of chronic diseases that cause immunosuppression and frailty $[9,10]$.

Orbital mucormycosis has been postulated as one of the main challenges of ophthalmology today [2, 3, 6-8]. Its early diagnosis and approach are essential to avoid the spread of infection and total involvement of the eye globe, bone structures, soft tissues, or central nervous system, which increases the risk of sepsis, neuro infection, and death $[2,3,6-8]$. Studies and case series have reported that long-standing or recently diagnosed 
Table 1. Summary of selected studies reporting orbital mucormycosis during COVID-19 and post-COVID 19 syndrome

\begin{tabular}{|c|c|c|c|c|}
\hline Authors & $\begin{array}{l}\text { Time from onset } \\
\text { of symptoms } \\
\text { COVID-19 to } \\
\text { onset of orbital } \\
\text { mucormycosis }\end{array}$ & Description & Management & $\begin{array}{c}\text { Final } \\
\text { outcome }\end{array}$ \\
\hline $\begin{array}{l}\text { Mohammadi } \\
\text { et al., } 2021 \text { [1] }\end{array}$ & 14 days & $\begin{array}{l}\text { A } 59 \text {-year-old non-diabetic male patient without any } \\
\text { underlying disease with a diagnosis of COVID-19. Fourteen } \\
\text { days after initiating management for COVID-19 with remdesivir } \\
\text { and methylprednisolone. The patient developed nasal } \\
\text { obstruction and left side facial and orbital swelling. In sinus } \\
\text { endoscopic surgery, severe involvement and necrosis of the } \\
\text { left-side lateral nasal wall, floor, and septum as well as left } \\
\text { ethmoid and sphenoid sinuses were observed, and also the } \\
\text { destruction of the left orbital floor and medial wall }\end{array}$ & $\begin{array}{l}\text { Liposomal } \\
\text { amphotericin B (i.v.) } \\
\text { Surgical debridement }\end{array}$ & Dead \\
\hline $\begin{array}{l}\text { Arora et al., } \\
2021 \text { [2] }\end{array}$ & $\begin{array}{c}17 \text { days } \\
\text { (from } 0 \text { to } 47 \text { days) }\end{array}$ & $\begin{array}{c}\text { Among the studied patients }(n=60), 58 \%(35) \text { belonged to } \\
\text { stages } 3 \text { and } 4 \text { and had unilateral orbital involvement, ptosis } \\
\text { being the most typical ocular manifestation. A chance of early } \\
\text { detection was higher by } 64 \%(p=0.06) \text { in patients presenting } \\
\text { with the ocular sign or symptoms and by } 42 \%(p=0.1) \text { in } \\
\text { patients who had not received systemic steroids }\end{array}$ & $\begin{array}{l}\text { Liposomal amphotericin } \\
\qquad \text { B (i.v.) } \\
\text { Transcutaneous } \\
\text { retrobulbar amphotericin B } \\
\quad \text { injection }\end{array}$ & $\begin{array}{c}\text { Not } \\
\text { mentioned }\end{array}$ \\
\hline $\begin{array}{l}\text { Nair et al., } \\
2021 \text { [3] }\end{array}$ & $\begin{array}{c}14.2 \text { days } \\
\text { (from } 9 \text { to } 22 \text { days) }\end{array}$ & $\begin{array}{l}\text { The mean age of the patients }(n=13) \text { was } 35.9 \text { years } \\
(20-51 \text { years). Five patients }(38.4 \%) \text { received retrobulbar } \\
\text { amphotericin-B injections. The globe was salvaged in } 4 \text { of } \\
\text { them. Before the COVID-19 infection, none of the patients } \\
\text { were on insulin or other oral hypoglycemic drugs. None of the } \\
\text { patients had any systemic co-morbiditie. }\end{array}$ & $\begin{array}{l}\text { Surgical debridement } \\
\text { Systemic amphotericin B } \\
\text { Retrobulbar amphotericin B } \\
\text { injections }\end{array}$ & All alive \\
\hline $\begin{array}{l}\text { Palou et al., } \\
2021 \text { [4] }\end{array}$ & 22 days & $\begin{array}{l}\text { A } 56 \text {-year-old male with no significant past medical history } \\
\text { was diagnosed with COVID-19. He received dexamethasone } \\
\text { for } 22 \text { days as an outpatient. A month later, he exhibited } \\
\text { inflammatory changes in his right hemiface accompanied } \\
\text { by intense headache, diplopia, decreased visual acuity } \\
\text { in the right eye, amaurosis, and signs of right periorbital } \\
\text { cellulitis. Destruction of the superior turbinate region was also } \\
\text { observed. Occupation of the maxillary sinus on the left side } \\
\text { related to sinusitis on the left side was also evident }\end{array}$ & $\begin{array}{l}\text { Liposomal amphotericin B } \\
\text { Imipenem } \\
\text { Vancomycin } \\
\text { Surgical debridement }\end{array}$ & Alive \\
\hline $\begin{array}{l}\text { Garg et al., } \\
2021 \text { [5] }\end{array}$ & $\begin{array}{c}24.6 \text { days } \\
\text { (from } 22 \text { to } 28 \\
\text { days) }\end{array}$ & $\begin{array}{l}\text { The predominant symptom in patients }(\mathrm{n}=10 \text { ) recovered from } \\
\text { COVID-19 infection was headache }(100 \%) \text {. Diminution of vision } \\
\text { was observed in } 3 \text { patients }(30 \%) \text {. All } 10 \text { patients }(100 \%) \text { were } \\
\text { treated with oral corticosteroids (as part of the management } \\
\text { of COVID-19 infection) for a mean of } 24 \text { days. All the patients } \\
\text { were treated with antibiotics and antihistamines post-surgery } \\
\text { and advised for nasal douching. Three of } 7 \text { patients }(42.8 \%) \\
\text { were diagnosed with mucormycosis, and } 1 \text { of } 3 \text { patients } \\
\text { (33.3\%) was diagnosed with aspergillosis }\end{array}$ & $\begin{array}{l}\text { Liposomal amphotericin B } \\
\text { Posaconazole }\end{array}$ & All alive \\
\hline $\begin{array}{l}\text { Mitra et al., } \\
2021 \text { [6] }\end{array}$ & $18( \pm 4)$ days & $\begin{array}{l}\text { In the group of } 32 \text { patients with a documented history of } \\
\text { SARS-CoV- } 2 \text { infection, } 78.1 \% \text { received steroid therapy, and } \\
28.1 \% \text { - high flow nasal oxygen ( } 12.5 \% \text { of patients were fully } \\
\text { vaccinated). } 87.5 \% \text { of patients reported blurring of vision, } \\
65.62 \% \text { - headache, } 59.37 \% \text { - cheek and eyelid swelling, } \\
50 \% \text { - proptosis, } 46.87 \% \text { - ophthalmoplegia, } \\
40.62 \% \text { - ptosis, } 40.62 \% \text { - loss of sensation over the cheek, } \\
\text { and } 25 \% \text { - orbital pain }\end{array}$ & $\begin{array}{l}\text { Endoscopic sinus surgery } \\
\text { Sinus debridement } \\
\text { Endoscopic } \\
\text { orbital clearance } \\
\text { and/or maxillectomy } \\
\text { and/or orbital exenteration } \\
\text { with adjuvant } \\
\text { Amphotericin B infusion }\end{array}$ & $\begin{array}{c}\text { Not } \\
\text { mentioned }\end{array}$ \\
\hline $\begin{array}{l}\text { Desai et al., } \\
2021 \text { [7] }\end{array}$ & Not mentioned & $\begin{array}{l}\text { In a group of } 100 \text { patients with a documented history of } \\
\text { SARS-CoV- } 2 \text { infection, the most common complaints were } \\
\text { headache and facial pain ( } 55 \% \text { ). } 25 \% \text { of patients had normal } \\
\text { vision, } 10 \% \text { were able to appreciate finger counting for }>6 \mathrm{~m} \text {, } \\
\text { and } 17 \% \text { were only able to appreciate hand movements. Even } \\
\text { projection of light was absent in } 22 \% \text { of patients. Normal eye } \\
\text { movements were observed in } 42 \% \text { of patients, while restricted } \\
\text { eye movements were present in } 58 \% \text { of patients }\end{array}$ & $\begin{array}{l}\text { Surgical debridement } \\
\text { Posaconazole syrup } \\
\text { Amphotericin B (i.v.) }\end{array}$ & $\begin{array}{l}20 \\
\text { deaths/20 } \\
\text { lost to } \\
\text { follow-up/ } \\
60 \text { alive }\end{array}$ \\
\hline
\end{tabular}




\begin{tabular}{|l|l|c|c|c|}
\hline Table 1. Summary of selected studies reporting orbital mucormycosis during COVID-19 and post-COVID 19 syndrome \\
\hline Authors & $\begin{array}{c}\text { Time from onset } \\
\text { of symptoms } \\
\text { COVID-19 to } \\
\text { onset of orbital } \\
\text { mucormycosis }\end{array}$ & Description & Management & $\begin{array}{c}\text { Final } \\
\text { outcome }\end{array}$ \\
\hline Sharma et al., & Not mentioned & $\begin{array}{c}\text { In a group of 23 patients with a documented history of } \\
\text { SARS-CoV-2 infection, 19 patients had been infected earlier } \\
\text { and recovered, and 4 patients tested positive at the time of } \\
\text { presentation but had been infected for more than 14 days. } \\
\text { The ethmoids (100\%) were the most common sinuses } \\
\text { affected. The intra-orbital extension was present in 43.47\% of } \\
\text { cases, while the intracranial extension was observed in 8.69\%. } \\
\text { Twenty-one patients were diabetic, and diabetes mellitus was } \\
\text { uncontrolled in 12 cases. }\end{array}$ & Surgical debridement \\
Amphotericin B & All alive \\
\hline
\end{tabular}

i.v. - intravenously

diabetes, elderly, and the use of corticosteroids during the acute phase of COVID-19 are the main factors associated with the development of orbital mucormycosis [1-8]. However, some cases have also reported orbital mucormycosis in immunocompetent and middle-aged patients $[1,4]$.

What is confusing and complicated in the early diagnosis of this ophthalmologic condition is its nonspecific presentation. Most present with headache [5-7] and nonspecific ocular signs [2,7], which may be associated with some phenotype of post-COVID 19 neurological syndrome or any other nonspecific neurological condition. Fortunately, although management is aggressive (surgical debridement, liposomal amphotericin B (i.v.), and transcutaneous retrobulbar amphotericin B injection), survival rates are high $[3-5,7,8]$. Particularly, Nair et al. [3] found that out of 13 patients, the overall globe salvage was possible in $42.8 \%$ (6/14 eyes), the globe could be preserved in 4/5 patients who received retrobulbar amphotericin B injections [3]. This is an important fact to highlight about the results of eye survival in pharmacological management.

However, there are no high-quality studies that have evaluated these survivors' functional capacity and quality of life to date. Considering then the global prevalence of diabetes mellitus and that due to misinformation and self-medication, many patients with the mild phenotype of COVID-19 consume corticosteroids without prescription, an increase in the number of cases of orbital mucormycosis with rhino-cerebral extension is expected in the near future. Some useful strategies would be the design of specialized groups for strict follow-up of COVID-19 patients with mild-to-moderate phenotype and home care and patients with the post-COVID-19 syndrome. Especially patients between 14 and 25 days from the onset of symptoms should be followed-up - in this period, according to the literature, manifestations of orbital mucormycosis appear [1-8]. Similarly, specialized rehabilitation centers should be created to reduce morbidity and mortality during the post-COVID 19 syndrome in order to reduce health costs and the overall burden of disease in the coming months and years. This is a new line of research that should be exploited to achieve advances in the field of ophthalmologic disease prevention and even in the understanding of the pathophysiology and tropism of SARS-CoV-2 infection.

\section{Conflicts of interest}

None declared.

\section{Funding}

None declared

\section{REFERENCES}

1. Mohammadi F, Badri M, Safari S, et al. A case report of rhino-facial mucormycosis in a non-diabetic patient with COVID-19: a systematic review of literature and current update. BMC Infect Dis. 2021; 21(1): 906, doi: 10.1186/s12879-021-06625-3, indexed in Pubmed: 34479495.

2. Arora R, Goel R, Khanam S, et al. Rhino-Orbito-Cerebral-Mucormycosis During the COVID-19 Second Wave in 2021 - A Preliminary Report from a Single Hospital. Clin Ophthalmol. 2021; 15: 3505-3514, doi: 10.2147/0PTH.S324977, indexed in Pubmed: 34429582.

3. Nair AG, Adulkar NG, D'Cunha L, et al. Rhino-orbital mucormycosis following COVID-19 in previously non-diabetic, immunocompetent patients. Orbit. 2021; 40(6): 499-504, doi: 10.1080/01676830.2021.1960382, indexed in Pubmed: 34338124. 
4. Palou EY, Ramos MA, Cherenfant E, et al. COVID-19 Associated Rhino-Orbital Mucormycosis Complicated by Gangrenous and Bone Necrosis-A Case Report from Honduras. Vaccines (Basel). 2021; 9(8), doi: 10.3390/vaccines9080826, indexed in Pubmed: 34451951.

5. Garg R, Bharangar S, Gupta S, et al. Post Covid-19 Infection Presenting as Rhino-Orbital Mycosis. Indian J Otolaryngol Head Neck Surg. 2021 [Epub ahead of print]: 1-8, doi: 10.1007/s12070-021-02722-6, indexed in Pubmed: 34307112.

6. Mitra S, Janweja M, Sengupta A. Post-COVID-19 rhino-orbito-cerebral mucormycosis: a new addition to challenges in pandemic control. Eur Arch Otorhinolaryngol. 2021 [Epub ahead of print], doi: 10.1007/s00405-021-07010-1, indexed in Pubmed: 34309754.

7. Desai EJ, Pandya A, Upadhya I, et al. Epidemiology, Clinical Features and Management of Rhino Orbital Mucormycosis in Post COVID 19 Patients. Indian J Otolaryngol Head Neck Surg. 2021 [Epub ahead of print]: 1-5, doi: 10.1007/s12070-021-02807-2, indexed in Pubmed: 34414101.

8. Sharma S, Grover M, Bhargava S, et al. Post coronavirus disease mucormycosis: a deadly addition to the pandemic spectrum. J Laryngol Otol. 2021; 135(5): 442-447, doi: 10.1017/S0022215121000992, indexed in Pubmed: 33827722.

9. González-Herazo MA, Silva-Muñoz DC, Guevara-Martínez PA, et al. Post-COVID 19 Neurological Syndrome: a fresh challenge in neurological management. Neurol Neurochir Pol. 2021; 55(4): 413-414, doi: 10.5603/PJNNS.a2021.0052, indexed in Pubmed: 34346051.

10. Camargo-Martínez W, Lozada-Martínez I, Escobar-Collazos A, et al. Post-COVID 19 neurological syndrome: Implications for sequelae's treatment. J Clin Neurosci. 2021; 88: 219-225, doi: 10.1016/j.jocn.2021.04.001, indexed in Pubmed: 33992187. 